\title{
THE LAND MOLLUSCAN FAUNA OF BRITISH NEW GUINEA.
}

\author{
By C. Hedley, F.L.S., Corr. Mem.
}

(Plates IX.-XII. and XII. bis.)

To naturalists generally the "Land of the Bird of Paradise" has ever been a source of interest, but to Australian students such a land, whose past history is intimately bound up with that of our own continent, should be especially attractive. Many archaic forms doubtless survive in that vast unknown region whose mountains, the loftiest in Australasia, possess every climate from the cold zone above the tree line to the tropical jungles of the littoral. Twenty years ago the coast of British New Guinea was a blank on the map, being less known than that of any country outside the Polar regions, and to-day the interior is almost entirely unexplored. What scanty information we possess concerning its fauna and flora is, therefore, of recent date. The first fruits of the conchological harvest were gathered by the naturalists of H.M.S. "Rattlesnake," who visited the Louisiades in 1849-50, and described by Forbes in an appendix to the account of that voyage. Sir W. Macleay, in 1875 , touched at Yule Island in the "Chevert," in which neighbourhood many new species were obtained by his staff, descriptions of which by Brazier will be found in the earlier volumes of this Society's Proceedings. During the same and following years D'Albertis amassed, both on Yule Island and the Fly River, a fine collection of mollusca which were subsequently treated of by Tapparone-Canefri (Annali del Museo Civico di Genova, xix.). A trader and collector, Mr. A. Goldie, procured many shells during various excursions along the coast and in the interior, most of which went to the British Museum, and were described by Smith in the Annals and Magazine of Natural History. In 1889 a 
collection was made by Sir W. Macgregor's party in the Louisiades ; this was presented to the British Museum and was also described by Smith.

British New Guinea comprises the south-eastern quarter of Papua with the adjacent reefs and islands, except those falling within the Queensland boundary, between the meridians of $141^{\circ}$ and $155^{\circ}$ of $\mathrm{E}$. longitude, and the parallels of $8^{\circ}$ and $12^{\circ}$ of $\mathrm{S}$. latitude. Though these political boundaries do not form the natural limits of the fauna, it will be more convenient to restrict ourselves to the consideration of the mollusca of the British province. For while the collections made in foreign colonies are described by foreign writers in a foreign language, and the types deposited in more or less inaccessible museums, the specimens obtained in the British area are naturally referred to British or Australian naturalists. Information regarding this fauna is so scattered through various publications that I believe that I have consulted the convenience of future inquirers by adding to the results of my own researches a summary of the labours of my predecessors.

For an opportunity of investigating this interesting region I am indebted to Sir William Macgregor, M.D., K.C.M.G., Administrator of British New Guinea, whose guest I was from May to August, 1890, and under whose auspices I was enabled to visit the St. Joseph River,* Milne Bay, \&c. I take this occasion to record my thanks both to his Honor and to the gentlemen of his staff who so often and so kindly assisted me in my scientific pursuits.

Part of the material dealt with in this communication I collected personally, part was spoil of the Fly River expedition of the previous year, part was obtained for me under the directions of Sir William by Messrs. Kowald and Belford in the Louisiade, Trobriand, and Woodlark Archipelagos, and for part I am indebted to Messrs. Masters and Brazier, of the Macleay and

* Only the latest maps show the St. Joseph River, which rises under Mt. Yule and flows into Hall Sound. 
Australian Museums respectively. To Mr. Brazier I am particularly obliged for much information, assistance in determining species, and for the loan of notes, papers, and specimens.

The land shells of the province exhibit four rather distinct geographical divisions :-

(a) The alpine fauna, whose sole known member is Rhytida globosa. Judging from the flora of these altitudes, as studied by Baron von Mueller (Trans. Roy. Soc. Vic. I. pt. 2, p. 1), the mollusca will probably exhibit affinities with those of Tasmania or Victoria. Cystopelta and Paryphanta are forms whose discovery may be anticipated.

(b) Secondly, that region lying between Port Moresby and the Fly River. Typical of this area are Hadra broadbenti, Geotrochus taylorianus, and Helicina coxeni. From this fauna the tropical mollusca of Queensland were perhaps derived, the colonists migrating across the dry bed of Torres Straits. Proceeding along the coast eastwards from Hula and Aroma to Orangerie Bay, we pass through a district quite unknown.

(c) A third province commences at South Cape Island in the west and includes all the eastern extremity of New Guinea with the outiying islands of Loggia, Samarai, Sarabai, Seidea, and Basilaki, or as they were formerly called Heath, Dinner, Hayter, Basilisk, and Moresby. I believe that the north-east coast will fall within this province whose typical members are Hadra rehsei, Nanina hunsteini, and Geotrochus brumeriensis.

(d) The fourth fauna inhabits the Louisiade, the Dentrecasteaux, * the Trobriand, and the Woodlark Archipelagos. Characteristic forms are the Geotrochi allied to louisiadensis, and the gigantic Pupinellæ allied to grandis. Of some species, Nanina divisa, Chloritis leei, and Helicina insularum for example, each island appears to possess a form, generally a variation peculiar to it. Many species have, through the blunders of unscientific collectors, been ascribed to the Dentrecasteaux Islands. I have

* The spelling of this name here adopted is not the version usually accepted but that of the official account of Dentrecasteaux's Voyages. 
myself collected G. rollsianus and P. brazierce upon Fergusson Island, and these, with the ubiquitous $L$. vitreum, are the only land shells yet known as indigenous to the group. These two characteristic forms would indicate that the fauna of these magnificent mountain islands will prove to be related rather to that of the distant Louisiades than to that of the nearer mainland.

\section{Oxytes hercules, n.sp.}

(Plate IX., figs. 1-2.)

Shell narrowly perforate, solid, large, orbicular, depressed, sharply keeled at the periphery; colour, above brownish-yellow, darkening as the whorls increase, on the base chestnut radiately painted with brownish-yellow, these tints reside solely in the epidermis beneath which the shell is livid, peristome pink; whorls $6 \frac{1}{2}$, slowly and regularly increasing, above flattened; sculpture, fist three whorls nearly smooth showing minute granulations under the lens, on the outer whorls a few faint impressed spiral lines are decussated by coarse irregular oblique costæ, between which are microscopic waved hair lines, at right angles to these are short straight indentations, on approaching the aperture the sculpture grows rougher and more uneven; apex obtuse, apical whorls minute with no break in colour or form to indicate an embryonic shell; suture impressed, deepening as it proceeds; buse rounded, gently curving in to the umbilicus, faintly spirally and radiately striated; epidermis glossy, scaling off readily in large flakes; aperture not descending, oblique, angularly lunate, peristome thickened internally, the base of the columella thickened, reflected over and nearly covering the perforation, margins of the peristome connected by a thin white semi-transparent callus. Diam. maj. 66, min. 55, alt. $30 \mathrm{~mm}$.

Ty p e in Queensland Museum.

$\mathrm{H}$ a bi t a t.-Fly River (Macgregor); a single example. There is an unlocalised specimen in Dr. Cox's collection, and another in the Australian Museum, each measuring 62:48:29 mm. 
This fine shell, the largest yet discovered in New Guinea, is, with the following species, closely allied to $N$. dorice, T.-C., and probably to $H$. achilles, Braz. Unfortunately my specimens consist only of dead shells, and as Tapparone gives no anatomical characters, the generic position of the group remains a matter of conjecture.

\section{O. Flyensis̊, n.sp.}

(Plate IX., figs. 3-4.)

Shell hardly perforate, solid, large, orbicularly turbinate, acutely angled at the periphery, angle disappearing in the latter part of the last whorl; colour shell white, a broad black band edged balow with reddish-brown encircling the base beneath the periphery, epidermis olive-green through which the peripheral band is visible, peristome pink; whorls 6 , slowly and regularly increasing, above rather convex; sculpture, first three whorls nearly smooth, showing regular delicate oblique ribs under the lens, outer whorls with coarse irregular oblique striæ, between which are microscopic waved hair lines, confusedly malleated, sculpture coarser on the last whorl; apex obtuse, apical whorls minute, no definition of embryonic whorls ; suture impressed, deepening as it proceeds; base rounded, umbilical region impressed, coarsely radiately striated; epidermis glossy, deciduous; aperture oblique, angularly lunate, peristome thickened and bent inwards, the base of the columella spread over almost all the umbilicus, margins not connected by a callus. Diam. maj. 60 , min. 49 , alt. $34 \mathrm{~mm}$.

Ty $\mathrm{p}$ e in Queensland Museum.

H a bit a t.-Fly River (Macgregor); three dead shells.

\section{$3 .^{*}$ Nanina citrina, Linné, 1759.}

Illu strations.-Chem. Conch. Cab. Ix. pl. 131, figs. 1170, 1172, 1173 ; Pfeiffer, Conch. Cab. 2nd ed. pl. 35, figs. 1, 2, 3; Voy. "Astrolable," Zool. II. pl. 11, figs. 1, 2, 3, 4; Voy. "Uranie et Physicienne," Zool. pl. 67, figs. 2, 3; Ostas. Zool. II. pl. 6,

* Species thus distinguished extend beyond the boundaries of British New Guinea. 
figs. 1-12, pl. 7 ; Reeve, Conch. Icon. vil. pl. 89, fig. 482a, b, c, d ; Tryon, Man. Conch. (2), II. pl. 20, figs. 88-95 ; \&c., \&c.

Descriptions.-Linné, Syst. Nat. ed. 10, p. 771 ; Mon. Hel. Viv. I. p. 53 ; Voy. "Astrolable," Zool. II. p. 140 ; Voy. " Uranie et Physicienne," Zool. p. 471 ; Voy. "Coquille," Zool. II. p. 306 ; Ostas. Zool. II., p. 193 ; Lamarck, An. s. Vert. vi. pt. 2, p. 77 ; Tryon, Man. Conch. (2), II. p. 72 ; \&c., \&c.

A n a t o m y.-Semper, Reis. Philipp. III. p. 63, pl. 3, fig. 13a, b, pl. 6, fig. 30 ; Ann. Mus. Gen. xıx. pl. 8, fig. 2.

Ty pe in Linnean Society's Museum, London.

H a bitat.-Douglas River (Bevan), Fly River (Froggatt), foot of Owen Stanley Range (Goldie).

4. N. hunsteini, E. A. Smith, 1887.

I 11 u s$^{\text {n. }}$ Ann. Mag. Nat. Hist. (5), xix. pl. 15, figs. 6 .

D e s c r. ${ }^{\text {n. }}$ L.c. (5), xix. 416.

$\mathrm{T} y \mathrm{p}$ e in British Museum.

$\mathrm{Hab}$ - - Not foot of Astrolabe and Owen Stanley Ranges (Goldie fide Smith), but Milne Bay (Hedley).

Found upon the hills under rotten palm spathes. Animal measures $70 \mathrm{~mm}$. from pedal horn to base of tentacles, tentacles $18 \mathrm{~mm}$., pedal horn $6 \mathrm{~mm}$. in length; colour reddish-chestnut darkening into black, tentacles black; mantle margin when fully extended reaching in front over the proximal third of the neck, on the right side down to the pedal line, right shell lobe triangular covering the apex of the shell, and reaching past it to the ultimate whorl, left shell lobe narrow, tongue-shaped, stretching along the last whorl for $12 \mathrm{~mm}$. ; tentacles tapering from contiguous bases ; pedal line well marked; upper surface of tail impressed deeply with a central furrow, whence the surface slopes upwards to an acute keel on either side thence descending perpendicularly to the margin of the foot; horn slender, smooth, as is also the adjoining portion of the tail, incessantly waved from side to side; mucous gland excavated into the tail above two lobes. 
5. N. fraudulenta, E. A. Smith, 1887.

D e s c r ${ }^{\mathrm{n}}$-Ann. Mag. Nat. Hist. (5), xix. 417.

Ty pe in British Museum.

$\mathrm{H}$ a b._Foot of Astrolabe Range (Goldie fide Smith)?

6. N. CaIrni, E. A. Smith, 1887.

I 11 u s$^{\text {n. }}$-Ann. Mag. Nat. Hist. (5), xix. pl. 15, fig. 5.

D e s c r. ${ }^{\text {n. }}$ L.c. (5), xix. 417.

$\mathrm{T}$ y $\mathrm{pe}$ in British Museum.

$\mathrm{H}$ a b.-Foot of Astrolabe and Owen Stanley Ranges (Goldie fide Smith).

7. N. Exilis, Muller, 1774 (?)

I $11 \mathrm{u} \mathrm{s}^{\mathrm{n}}$ - Ann. Mag. Nat. Hist. (5), xIx. pl. 15, fig. 13.

D e s c r ${ }^{\text {n. }}$-L.c. (5), xIx. 418.

Specimens I gathered near Aipiana resemble Smith's figure.

8. N. DIvisa, Forbes, 1852.

I 11 u s s. -Voy. "Rattlesnake," II. pl. 2, figs. 5 a-b; Reeve, Conch. Icon. vir. pl. 205, fig. 1450 ; Tryon, Man. Conch. (2), II. pl. 13, fig. 70 .

D e s c r.-Mon. Hel. Viv. III. p. 77 ; Voy. "Rattlesnake," II. Append. p. 376 ; Tryon, Man. Conch. (2), II. 39.

Ty pe in British Museum.

$\mathrm{H}$ a b.-Sudest Island, Louisiades (Forbes, Kowald and Belford).

var. inclinata, Pfeiffer, 1863.

I $11 \mathrm{u} \mathrm{s}^{\mathrm{n}}$ - -Ann. Mag. Nat. Hist. (6), Iv. pl. 13, fig. 16.

D e s c rn.-P.Z.S. 1863, p. 526; Mon. Hel. Viv. v. p. 129.

Ty pe in British Museum.

$\mathrm{H}$ a b._St. Aignan or Misima (Thomson, Kowald and Belford). 
var. rosseliana, Smith, 1889.

Ill u s ${ }^{\text {n. }-A n n . ~ M a g . ~ N a t . ~ H i s t . ~(6), ~ I v . ~ p l . ~ 13, ~ f i g . ~} 15$.

D e s c r ${ }^{\text {n. }}$-L.c. (6), Iv. 200.

$\mathrm{T}$ y $\mathrm{pe}$ in British Museum.

H a b.-Rossel Island (Thomson).

var. minor, var.nov.

Resembling the type in outline but smaller and lighter in colour. Diam. maj. 22, min. 19, alt. $11 \mathrm{~mm}$.

$\mathrm{T}$ y p e in Queensland Museum.

Ha b._-Mita, Milne Bay (Hedley).

var. woodlarkensis, var.nov.

More globose than type, much inflated around the umbilicus. Diam. maj. 31, min. 27, alt. $17 \mathrm{~mm}$.

Ty pe in Queensland Museum.

$\mathrm{H}$ a b. - Woodlark Island (Kowald and Belford); one specimen.

9. N. orbiculum, Tapparone-Canefri, 1883.

Ill u s s.

Descrn.-L.c. p. 204.

A n a t.-L.c. xix. pl. 7, fig. 7 .

Ty pe in Genoa Museum.

H a b.-Fly and Katow Rivers (D'Albertis).

10. N. BRUiJni, Tapparone-Canefri, 1883.

I1lu s ${ }^{n}$.-Ann. Mus. Gen. XIX. pl. 5, figs. 13, 14, 15.

Descrn. -L.c. p. 206.

Ty pe in Genoa Museum.

$\mathrm{H}$ ab.-Fly and Katow Rivers (D'Albertis). 


\section{Conulus starkei, Brazier, 1876.}

(Plate Ix., fig. 5.)

D e s c rn.-P.L.S.N.S.W. (1), I. 103; Ann. Mus. Gen. xIx. p. 98.

Ty pe in Macleay Museum.

$\mathrm{H}$ a b. - Yule Island (Brazier); in scrub on the hills behind the village of Maiva, in scrub on Mission Hill, beach just above high tide mark Port Moresby, beach ditto Mita, Milne Bay (Hedley). Mr. Brazier's type specimen is here figured by kind permission of Mr. Masters.

The following extract from my note-book refers to a Mita specimen :-Animal translucent; when extended foot not reaching to posterior margin of shell, tail keeled and diagonally grooved, terminating in a mucous pore, surmounted by a small horn; foot margined with a pedal line; tentacles short, cylindrical, bases separate.

This species should be compared with such forms as subrugosa, Garrett, from Fiji.

12. C. maino, Brazier, 1876.

(Plate IX., fig. 6).

D e s c r ${ }^{\text {n. }}$-P.L.S.N.S.W. (1), I. 101; Ann. Mus. Gen. xIx. p. 97 $\mathrm{T}$ y $\mathrm{p}$ e in Macleay Museum.

$\mathrm{H}$ a b.-Yule Island (Brazier).

Figured from the type.

13. Microcystina sappho, Brazier, 1876 .

(Plate Ix., fig. 7.)

D e s c r ${ }^{\text {n. }}$-P.L.S.N.S.W. (1), I. 100; Ann. Mus. Gen. xIx. p. 95.

Ty pe in Macleay Museum.

H a b.-Yule Island (Brazier); Maiva and Mission Hill, in company with C. starkei (Hedley).

Figured from a Maivan specimen. 
14. M. Calcarata, n.sp.

(Plate Ix., fig. 8, and Pl. x., fig. 9.)

Shell small, subdiscoidal, perforate, thin, translucent; colour dark chestnut, apical whorls straw-coloured; whorls $4 \frac{1}{2}$, rounded, slowly increasing; sculpture, to the unassisted eye the surface is smooth and glossy, but the microscope shows extremely fine radiating waved hair lines; spire scarcely elevated, embryonic whorls 2, distinct; suture channelled, margined beneath by a heavy opaque callus; base flattened, umbilicus narrow triangular, circum-umbilical region funnel-shaped; aperture not descending, vertical, ovate lunate, peristome straight, thin, columellar margin thickened and produced into a callous spur overhanging the umbilicus, callus on body whorl thin and microscopically granulated. Diam. maj. $2 \frac{1}{2}$, min. $1 \frac{1}{2}$, alt. $1 \mathrm{~mm}$.

$\mathrm{T}$ y $\mathrm{pe}$ in Queensland Museum.

H a b.-Associated with $C$. starkei and $P$. pedicula under sticks and stones, near the beach, 200 yards west of Mita village, Milne Bay (Hedley).

I have here accepted the value given to the badly defined section of Microcystina by Tryon (Man. Conch. (2), II. 124.) These Papuan species are probably allied to the Fijian forms there enumerated.

\section{Helicarion visi, n.sp.}

(Plate x., fig. 13.)

Shell depressed, thin, brittle, glossy, transparent; colour pale yellow; whorls $3 \frac{1}{2}$, rather rapidly increasing, rounded at the periphery; sculpture fine incremental striæ; suture margined, impressed, base imperforate, impressed in the centre, swollen around it ; aperture diagonal, ovate lunate, peristome thin, simple, margins joined by a slight callus, columellar margin reflected. Diam. maj. 8, min. 7, alt. $4 \mathrm{~mm}$.

$\mathrm{T}$ y pe in Queensland Museum.

$\mathrm{H}$ a b.-Basilaki Island; six examples under sticks and stones in the jungle (Hedley). 
The length of the largest spirit specimen, from muzzle to mucous pore, was $20 \mathrm{~mm}$., the tail extending posteriorly half that distance from the visceral hump. General colour light yellow, upper surface of tail, mantle lobes, neck, and tentacles bluish-gray. Tail subkeeled, scarcely diminishing in height posteriorly, suddenly increasing at caudal extremity and terminating abruptly, bearing a well-developed mucous pore above the pedal groove; a dorsal central groove runs the length of the tail distributing oblique branches which reach the pedal groove. The mantle is divided into left and right triangular shell lobes and two neck lappets. From the lips a well-defined pedal line extends to the mucous pore, from the pulmonary orifice and from a corresponding position on the left side another groove runs to the lips.

The jaw is that of a typical Helicarion, smooth, lunate, with inferior median limb.

In the odontophore the rows of teeth curve slowly backwards from the rachidian, which has a slender ovate median cusp and two small accessory cusps, the laterals develop only the distal cusp, and their main cusp is longer and broader than that of the rachidian; after being repeated for twelve rows this type is succeeded by 20 small unicuspidate marginals.

This species, the first of its genus recorded from New Guinea, is dedicated to C. W. de Vis, Esq., M.A., Director of the Queensland Museum, as a slight token of the author's regard and gratitude for numberless kind actions.

\section{H. musgravei, n.sp.}

(Plate x., fig. 14.)

Shell globose, thin, brittle, transparent ; pale yellow ; whorls $3 \frac{1}{2}$, rounded; suture impressed, margined, sculpture minute incremental striæ; base imperforate, impressed in the centre, swollen around it ; aperture oblique ovate lunate, lip thin, simple, margins connected by a slight callus, columellar margin reflected. Diam. maj. 6 , min. 5 , alt. $4 \mathrm{~mm}$.

Ty p e in Queensland Museum. 
H a b.-Doura (Hedley).

Named after the Hon. A. Musgrave, of British New Guinea.

17. $\dagger$ Thalassia annula, Brazier, 1876.

(Plate x., fig. 10.)

D e s c rn.-P.L.S.N.S.W. (1), I. 100 ; Ann. Mus. Gen, xix. p. 94.

Ty pe in Macleay Museum.

H a b.-Village of Mowatta, mouth of Katow River (Brazier).

Figured from type.

Doubtful,-T. rustica, Pfr., supposed by Mr. Petterd to exist near Port Moresby (vide Journ. of Conch. I. p. 396 ; Ann. Mus. Gen. xxiv. p. 125 bis.).

18. †Trochomorpha planorbis, Lesson, 1830.

Ill u s".-Voy. "Coquille," Moll. pl. 13, figs. 4, 4', 4"; Pfeiffer, Conch. Cab. 2 ed. Helix, II. pl. 129, figs. 16, 17 ; Mousson, Land Sussw. Moll. Java, pl. 2, fig. 9 ; Martens, Ostas. Zool. pl. 13, figs. 4, 5, 6, 7 ; Tryon, Man. Conch. (2), III. pl. 16, figs. 78-82 ; \&c., \&c.

D e s c r n.-Pfeiffer, Mon. Hel. Viv. I. p. 122 ; Voy. "Coquille," Zool. II. p. 312 ; Tryon, Man. Conch. (2), III. 82 ; \&c., \&c.

Ty pe in Museum of the Jardin des Plantes.

Hab.-Fly River (D'Albertis, Froggatt); Katow River (D'Albertis).

19. T. Lomonti, Brazier, 1876.

Ill u sn.-Ann. Mus. Gen. xix. pl. 2, figs. 5, 6, 7 ; Tryon, Man Conch. (2), III. pl. 15, figs. 50, 51, 52.

De s c r ${ }^{\text {n. }}$-P.L.S.N.S.W. (1), I, 101 ; Ann. Mus. Gen. xix. p. 91 ; Tryon, Man, Conch. (2), III. p. 82.

A n a t.-Ann. Mus. Gen. pl. 6, fig. 2, pl. 8, fig. 3, pl. 9, fig. 4.

T y p e in Macleay Museum.

H a b.-Yule Island (Brazier, D'Albertis.) 
20. T. Nigrans, E. A. Smith, 1889.

Ill u s${ }^{\mathrm{n}}-A$ nn. Mag. Nat. Hist. (6), Iv. pl. 13, figs. 9, 10, 11.

D e s c r ${ }^{\text {n. }}$-L.c. p. 200.

$\mathrm{T}$ y $\mathrm{pe}$ in British Museum.

H a b. - Rossel Island (Thomson, Belford and Kowald).

var. cornea, var.nov.

Smaller than type, horn-coloured. Diam. maj. 16, min. 14, alt. $6 \mathrm{~mm}$.

Ty p e in Queensland Museum.

$\mathrm{H}$ a b.-Sudest Island (Kowald and Belford) ; one specimen.

21. Ochthephila albertisi, Brazier, 1876.

(Plate x., fig. 11.)

De s c rn.-P.L.S.N.S.W. (1), I. 104 ; Ann. Mus. Gen. xix. p. 183.

Ty pe in Macleay Museum.

$\mathrm{H}$ a b.-Yule Island (Brazier).

Figured from the type. The generic position of this species is doubtful.

\section{Charopa texta, n.sp.}

(Plate x., fig. 12.)

Shell depressed turbinate, thin, perforate, glistening; colour reddish-corneous; whorls $4 \frac{1}{2}$, rounded, flattened beneath the suture; sculpture strong sinuate oblique radiating ribs, of which the last whorl possesses about 60 , in each interstice and parallel to the ribs are 4 or 5 fine raised hair lines, decussating these secondary costæ and of the same calibre are raised spiral lines, which are most prominent on the spire and base; epidermis possessing a silky sheen; suture deeply impressed; apex not prominent, embryonic whorls $1 \frac{1}{2}$, shining, nearly smooth, but faintly repeating the adult sculpture; umbilicus narrow, deep, spiral ; base rounded ; aperture oblique, roundly lunate, peristome 
straight, sharp, columellar margin reflected. Diam. maj. 6, min. 5, alt. $4 \mathrm{~mm}$.

Ty pe in Queensland Museum.

H a b.-Mission Hill, Upper St. Joseph River (Hedley) ; two living specimens occurred to me under fallen timber in dense jungle.

\section{Rhytida globosa, Hedley, 1890.}

(Plate x., figs. 15-16.)

Descrn.-Annual Report of British New Guinea, 1888-89, p. 65 .

Shell depressed-globose, thin, translucent, perforate, very glossy ; whorls $4 \frac{1}{2}$, the earlier flattened, the later rounded, rather rapidly increasing, the last a little expanded, not descending at the aperture; colour reddish-chestnut above, lighter beneath, first three whorls bleached nearly white; sculpture almost effaced on the body whorl, where nearly obsolete spiral impressed lines cross the faint irregular growth lines, the earlier whorls exhibit fine close oblique striæ cut by fine spiral grooves, a pitted (not striated) surface is offered by the first whorl and a-half, which seem embryonic; suture impressed, slightly crenulated, bordered beneath by a narrow white band, which is in turn edged by a black line; aperture ovate, oblique, peristome simple above, slightly reflected below ; interior bluish-white, probably iridescent when fresh, columellar wall overlaid by a thin deposit; umbilicus narrow, partially hidden by the reflected peristome at its junction with the base; base a little inflated. Diam. maj. 17, min. 14, alt. $10 \mathrm{~mm}$.

Ty p e in Queensland Museum.

$\mathrm{H}$ a b.-Mt. Victoria, the culminating point $(13,000 \mathrm{ft}$.) of the Owen Stanley Range (Macgregor).

Near a village on the south shore of Milne Bay whose name I do not know, but which may be identified by its position directly south of Mita, I found, in company $H$. rehsei, C. horridus, and $O$. brazieri, a shell differing from but closely resembling Patula 
fabrefacta, Pease. I cannot venture to describe the species from my single dead and bleached specimen, but can only record the existence in New Guinea of a group hitherto regarded as peculiar to the Eastern Pacific.

24. Cristigibba rhodomphala, Tapparone-Canefri, 1883.

Ill u s${ }^{n}$. Ann. Mus. Gen. xix. pl. 4, figs. 12, 13.

Desc r ${ }^{\text {n}}$-L.c. xix. p. 176.

Ty pe in Genoa Museum.

var. alpha.

Hab.-Fly River (D'Albertis, Froggatt); Douglas River (Bevan); Mission Hill (Hedley).

25. C. plagiocheila, Tapparone-Canefri, 1883.

I 11 u s$^{\text {n. }}-A n n$. Mus. Gen. xix. pl. 5, figs. 4, 5, 6, 7 .

D e s c r ${ }^{\text {n. }-L . c . ~ X I x . ~ p . ~} 174$.

A n a t.-L.c. xix. pl. 7, fig. 6 .

$\mathrm{T}$ y pe in Genoa Museum.

H a b.-Fly and Katow Rivers (D'Albertis).

26. C. Dominula, Tapparone-Canefri, 1883.

Ill u s. ${ }^{\text {n. }}$ Ann. Mus. Gen. xix. pl. 4, figs. 8, 9, 10, 11.

Des c rn.-L.c. xIx. p. 178.

A n a t.-L.c. xıx. pl. 7, fig. 4, pl. 9, figs. 5, 14.

Ty p e in Genoa Museum.

vars. alpha, beta, delta.

H a b.-Fly and Katow Rivers (D'Albertis); Douglas River (Bevan).

27. C. Deaniana, Ford, 1890.

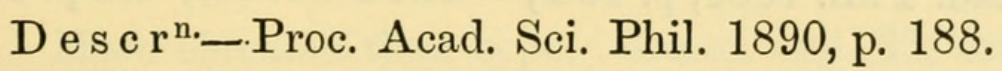

Ty pe in Phil. Acad. Museum.

H a b. - British New Guinea (Denton). 


\section{C. MACGREGORI, n.sp.}

(Plate x., figs. 17-19.)

Shell umbilicated, discoidal, thin, translucent; colour reddishbrown above, lighter beneath, peristome bright lilac, interior of shell subnacreous, iridescent, gleaming bluish-white; whorls $4 \frac{1}{2}$, rounded, the earlier gradually the last rapidly increasing, last descending considerably and gradually at the aperture and furnished with the gibbosity characteristic of the genus ; sculpture oblique flat-topped costæ whose shallow interstices contain two or three fine radiating striæ, both costæ and striæ are crossed by minute spiral grooves; apical whorls sunken, smooth; suture deeply impressed; aperture diagonal, lunate, peristome widely expanded above, reflected below, margins approaching, connected by a thin transparent callus, columellar margin expanded over a quarter of the umbilicus; the latter narrow, deep, showing every revolution of the spire, margin abruptly rounded. Diam. maj. 28, min. 21 , alt. $12 \mathrm{~mm}$.

Ty pe in Queensland Museum.

H a b.-Village of Aipiana, St. Joseph River (Hedley). Dead shells were seen in abundance, animals were purchased from the natives.

Dedicated to Sir William Macgregor, M.D., K.C.M.G., whose zeal for science has greatly increased the world's knowledge of the Papuan fauna and flora.

Recorded from the province in error.

C. corniculum, Hombr. et Jacq.

Vide Ann. Mag. Nat. Hist. (5), xi. 190, and Ann. Mus. Gen. xIx. p. 179 .

C. Dentoni, Ford, 1890 .

Vide Proc. Acad. Phil. 1889, p. 138; “The Nautilus," III. p. 17, 2 woodcuts.

Mr. Brazier assures me that this species is identical with (H.) tuckeri. Pfr., Queensland specimens of which frequently possess a 
continuous peristome, on which feature Ford bases his distinction. Before his death in New Guinea, Professor Denton visited Northern Queensland, where no doubt he collected Ford's specimens.

29. Chloritis dinodeomorpha, Tapparone-Canefri, 1883.

Ill u s${ }^{n}$-Ann. Mus. Gen. xix. pl. 4, figs. 4, 5, 6, 7.

Des c r ${ }^{\text {n. }}$-L.c. xix. p. 168.

A n a t.--L.c. xıx. pl. 7, fig. 5, pl. 9, figs. 2, 15.

Ty p e in Genoa Museum.

Hab.-Fly River (D'Albertis, Froggatt); Mission Hill, St. Joseph River (Hedley).

$$
\text { 30. C. Leei, Cox, } 1873 .
$$

Ill u s ${ }^{\text {n. }}$-P.Z.S. 1873, pl. 48, figs. 5, 5a.

Descrn. L.c. 1873 , p. 565 ; Mon. Hel. Viv. vir. p. 395 ; Ann. Mag. Nat. Hist. (6), Iv. 201.

Ty pe in Australian Museum.

$\mathrm{H}$ a b.-St. Aignan (Thomson fide Smith, Kowald and Belford).

var. woodlarkensis, var.nov.

Smaller than type, lip dark purple, umbilicus nearly hidden by the reflection of the columella. Diam. maj. 25, min. 20, alt. $18 \mathrm{~mm}$.

$\mathrm{H}$ a b. - Woodlark Island (Kowald and Belford).

var. sudestensis, var.nov.

Larger and more globose than type, lighter in colour, and umbilicus less overhung by the reflection of the columella. Diam. maj. 34 , min. 25 , alt. $26 \mathrm{~mm}$.

$\mathrm{H}$ a b.-Sudest Island (Kowald and Belford).

var. papuensis, var.nov.

More elevated than type. Diam. maj. 33, min. 25, alt. $26 \mathrm{~mm}$.

H a b.-Mita, Milne Bay, and Mr. Kissack's selection near Samarai (Hedley). 
How far these insular forms may be permanent my material is too scanty to satisfactorily decide.

31. C. subcorpulentus, E. A. Smith, 1889.

Ill u s ${ }^{\text {n. }}$-Ann. Mag. Nat. Hist. (6), Iv. pl. 13, fig. 14.

De s c rn. -L.c. p. 201.

Ty pe in British Museum.

H a b.-Rossel Island (Thomson).

In the jungle near Doura I found living with $H$. musgravei, a new species of Chloritis allied to the Queensland porteri. My specimens of it were accidentally crushed before reaching A ustralia.*

32. † HADra ReHSEI, von Martens, 1883.

Sy n o n y m-gerrardi, Smith, 1883.

I 11 u s$^{\text {n. }}$-Ann. Mag. Nat. Hist. (5), xix. pl. 15, fig. 14 .

De s c r ${ }^{\text {. }-J a h r b . ~ M a l a k . ~ G e s e l l . ~ 1883, ~ p . ~} 83$; Ann. Mag. Nat. Hist. (5), xI. 192 ; l.c. (5), xIx. 418.

Ty p e (?)

H a b.-Not Dentrecasteaux Islands (Goldie fide Smith), nor Dinner Island (Smithurst fide Brazier), but south shore of Milne Bay (Hedley).

33. H. Beatricis, Tapparone-Canefri, 1883.

Ill u s${ }^{n}$. Ann. Mus. Gen. xix. pl. 4. fig. 14.

D e s c r ${ }^{\text {n. }}$-L.c. xIx. p. 163.

A n a t.-L.c. xix. pl. 8, fig. 16 .

Ty pe in Genoa Museum.

H a b.-Fly River (D'Albertis, Froggatt).

34. H. Hixoni, Brazier, 1877.

I 11 u s$^{\text {n. }}-A n n$. Mus. Gen. xix. pl. 5, fig. 22 ; Tryon, Man. (2) vi. pl. 25, fig. 91.

D e s c rn. -P.L.S.N.S.W. (1), II. 120 ; Ann. Mus. Gen. xIx. p. 187 ; Tryon, Man. (2) vi. p. 177.

* Since this has been in type a description of this species as $C$. chloritoides Pilsbry, has reached me. 
Ty p e in Coll. Hobson.

Hab.-Weven miles inland from Hall Sound (Hixon fide Brazier).

35. H. BRoadbenti, Brazier, 1877.

I 11 u s$^{\mathrm{n}}$-Ann. Mus. Gen. xix. pl. 5, fig. 21 ; Tryon, Man. (2) vI. pl. 25, fig. 100 .

D e s c r ${ }^{\text {n. }-P . L . S . N . S . W . ~(1), ~ I I . ~} 25$; Ann. Mus. Gen. xix. p. 188 ; Tryon, Man. (2) vi. p. 176.

$\mathrm{T}$ y $\mathrm{pe}$ in Queensland Museum.

H a b.-Not Dentrecasteaux Islands (Goldie fide Smith), but Laloki River, near Port Moresby (Broadbent); village of Najabui (D'Albertis); St. Joseph River (Hedley).

Mr. Brazier has kindly furnished me with the following description :-

$$
\text { 36. “Helix bevani, Brazier, n.sp. }
$$

(Plate XI., figs. 22-23.)

"Shell umbilicate, depressed, sharply carinated at the periphery, thin, obliquely striated, reddish-brown with a dark nearly black narrow line at the centre, epidermis yellowish-brown; spire slightly elevated; apex dark pink ; suture moderately impressed ; whorls $4 \frac{1}{2}$, very slightly convex, last largest in front; umbilicus narrow, shallow; base flattened, striæ finer than upper surface; aperture hatchet-shaped; peristome black, slightly expanded and reflected, right margin at the upper part thin ; columellar margin broadly expanded and reflected over the umbilicus. Diam. maj. 45 , min. 35, alt. $18 \mathrm{~mm}$; height of aperture 12, breadth $21 \mathrm{~mm}$.

" Ty p e in Australian Museum.

"H a b.-Douglas River, British New Guinea (Bevan).

"This fine species is allied to Helix Goldei, Braz. ; a single dead specimen in a good state of preservation was found by Mr. Theodore F. Bevan, F.R.G.S., during his exploration of British New Guinea in 1887." 
37. Geotrochus oxystoma, E. A. Smith, 1883.

(Plate x., fig. 20, and Pl. xI., fig. 21.)

S y n.-goldiei, Brazier.

De s c r ${ }^{\text {n. }}$ Ann. Mag. Nat. Hist. (5), xi. 191 ; P.L.S.N.S.W. (1), Ix. 804.

Ty pe in British Museum.

$\mathrm{H}$ a b.-Not Dentrecasteaux Islands (Goldie fide Smith), but foot of Astrolabe Range (Goldie) and Doura, Galley Reach (Hedley).

By adopting Geotrochus as a generic title the necessity is obviated of discarding Smith's name, since oxystoma is not preoccupied in Geotrochus, though, as Brazier points out, it is in Helix. The figures which illustrate, though they hardly adorn, p. 173 of Stone's “Ten Months in New Guinea," are intended, I believe, to represent this species.

38. G. Elisus, n.sp.

(Plate XI., figs. 24-25.)

Shell umbilicate, thin, discoidal, carinate; colour pale straw, with two narrow reddish spiral bands, the superior midway between the suture and the periphery, the inferior encircling the base at a third of the distance from the keel to the umbilicus, the carina is sometimes edged above and below by similar bands, peristome white; whorls $4 \frac{1}{2}$, increasing regularly until the final whorl, which in its latter half contracts a little, the earlier whorls slightly convex, the latter flat; sculpture close, irregular oblique striations above and below, crossed by a few faint impressed lines in the neighbourhood of the keel; apex obtuse, the embryonic shell apparently constituting the first revolution; suture impressed above, becoming linear as it proceeds, margined above by the keel of the preceding whorl; base flattened at the periphery, slightly swollen within; umbilicus narrow, deep, exhibiting the volutions; aperture almost horizontal, abruptly and deeply descending, peristome thin, widely reflected throughout its circumference, pinched at the junction of the carina, margins closely approaching, 
connected by a transparent callus. Diam. maj. 29, min. 24, alt. $10 \mathrm{~mm}$.

The Macleay Museum contains four dead shells of this species, which appear to resemble $G$. pelechystoma, Tapp.-Can., purchased from Mr. Goldie, who collected them in British New Guinea.

39. G. taylorianus, Adams and Reeve, 1851.

Syn.-yulensis, Brazier, 1876 ; strabo, Brazier, 1876 ; katauensis, Tapparone-Canefri, 1883 ; roseolabiatus, Smith, 1887.

Ill u s".-Voy. "Samarang," Zool. pl. 15; 2a, 2b; Ann. Mag. Nat. Hist. (5), xIx. pl. 15, figs. 1, 1a, 2 ; Reeve, Conch. Icon. viI. pl. 96, No. 524, a, b; P.L.S.N.S.W. (2), II. pl. 21, figs. 5, 6 ; Ann. Mus. Gen. xıx. pl. 3, figs. 1, 2, 3.

D e s c r._-"Samarang", Zool. p. 59 ; P.L.S.N.S.W. (1), I. 106 ; Ann. Mus. Gen. XIx. p. 123, 125 ; Journ. of Conch. vi. p. 76 ; Ann. Mag. Nat. Hist. (5), xix. 421, \&c.

A n a t.-Ann. Mus. Gen. xıx. pl. 6, figs. 1, 3 ; pl. 8, fig. 11.

Type in British Museum.

$\mathrm{H}$ a b. - Yule Island and Katow River (Brazier and D'Albertis); St. Joseph River (Hedley); Fly River (Froggatt); Maclachie Point, Krema district, foot of the Albert Range of mountains (Goldie).

An examination of a large series of shells in the possession of Mr. Brazier induces me to consider G. taylorianus as a most variable form. The following prominent varieties are linked each to each by intermediate graduations :-

(a) yulensis; smaller than type, mottled with oblique irregular black dashes, which by transmitted light appear as translucent spaces. (Yule Island, J.B.)

(b) katauensis; encircled by black spiral bands. (Maclachie Point, Goldie.)

(c) strabo; a monochrome form with no clear mottled spaces; approaches nearest to taylorianus. (Maclachie Point, Goldie.) 
(d) roseolabiatus; with a black band at the suture and the periphery. (Maclachie Point, Goldie.)

This form is confined to western British New Guinea and the eastern localities quoted by Smith; South Cape and Dentrecasteaux Islands are to be discredited.

The history of the original specimen appears to have been lost. Since, before G. taylorianus was described, H.M.S. "Fly" was the only European vessel that visited the territory inhabited by this species, I conjecture that the type was procured in May, 1845 , by Jukes or MacGillivray during her voyage to this coast.

40. G. tapparonei, E. A. Smith, 1883.

(Plate XI., fig. 26.)

Syn.-hunsteini, Brazier, MSS.

D e s c rn. Ann. Mag. Nat. Hist. (5), xi. 190 ; P.L.S.N.S.W. (1), Ix. 805 .

Ty pe in British Museum.

H a b.-Not Dentrecasteaux Islands (Goldie fide Smith), but found by C. Hunstein fifty miles inland from Port Moresby, north of the Astrolabe Range, near the head of the Laloki River.

This and taylorianus approach the Australian G. macgillivrayi.

41. G. zeno, Brazier, 1876.

(Plate XI., fig. 27.)

D e s c rn.-P.L.S.N.S.W. (1), I. 107, (1), Ix. 805 ; Ann. Mus. Gen. xIx. p. 154.

Ty pe in Macleay Museum.

H a b.-Hall Sound (Brazier), between Rigo and Kappakappa (Hedley).

var. latiaxis, Smith, 1887.

I 11 u s$^{\text {n. }}-$ Ann. Mag. Nat. Hist. (5), xIx. pl. 15, fig. 7 ; Tryon, Man. Conch. (2), vi. pl. 17, fig. 16. 
D e s c r. -Ann. Mag. Nat. Hist. (5), xix. 420 ; l.c. (5), xi. 191. Type in British Museum.

$\mathrm{H}$ a b._Foot of Astrolabe and Owen Stanley Range (Goldie).

42. G. Diomedes, Brazier, 1878.

Ill u s s. $-A n n$. Mus. Gen. xix. pl. 3, fig. 12.

D e s c rn. P.L.S.N.S.W. (1), II. 121; Ann. Mus. Gen. xıx. 122.

Ty pe in Australian Museum.

$\mathrm{H}$ a b.-Not Brumer Island (Brazier), but Coutances Island* (Broadbent fide Brazier); and therefore not a member of the Louisiade fauna, as stated in Ann. Mag. Nat. Hist. (6), vir. 135.

A dead shell, too worn to be described, but evidently new, and related to the two last species, was collected by Sir W. Macgregor during his expedition to the Fly River in 1890.

43. †G. Brumeriensis, Forbes, 1852.

(Plate XI., fig. 29.)

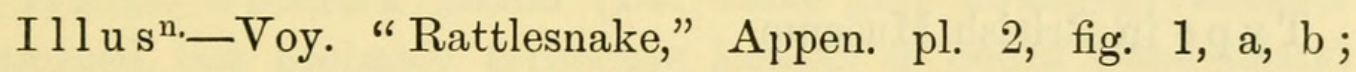
Reeve, Conch. Icon. vir. pl. 205, fig. 1448 ; Tryon, Man. (2), vi. pl. 12, figs. 41, 42, 43 .

Des crn.-Voy. "Rattlesnake," II. p. 375 ; Mon. Hel. Viv. III. p. 189 ; Ann. Mag. Nat. Hist. (5), xIx. 419.

Type in British Museum.

H a b.-Brumer Island (Forbes); Millport Harbour, Amazon Bay (Goldie fide Brazier); Bently and Milne Bays, South Cape, Samarai, Loggia and Basilaki Islands (Hedley).

var. albolabris, var. nov.

Lip entirely white.

Ty pe in Queensland Museum.

H a b.-Mita, Milne Bay.

* Coutances Island is situated in $148^{\circ} 10^{\prime} \mathrm{E}$. long., $10^{\circ} 15^{\prime} \mathrm{S}$. lat. 
G. brumeriensis inhabits heavy-limbed trees, preferring those with whitish bark, like Hibiscus tiliaceus and Artocarpus incisus. In its favourite perch, on the under side of the larger boughs, its resemblance to a knot renders it difficult to detect. Animal $60 \mathrm{~mm}$. in total length. Shell placed posteriorly. Tentacles slender, tapering, $15 \mathrm{~mm}$. long when fully expanded, bases four mm. apart. Tail flat, pointed. Tentacles jet black; head and neck ornamented by narrow white longitudinal tubercles on a black ground ; foot everywhere bordered above by a narrow band of intense black, above which is an ill-defined zone of greyish white merging above into black; sole of foot black at edges, whitish within ; mantle yellowish-white. Mucus unusually dense like that of the arboreal Limaces. Egg small, soft, white, oblong.

44. G. Louisiadensis, Forbes, 1852.

Illu s"-Voy. "Rattlesnake," Appen. pl. 1, figs. 8a, b; Reeve, Conch. Icon. viI. pl. 205, fig. 1449.

D es cr r. -Voy. "Rattlesnake," Appen. p. 376 ; Mon. Hel. Viv. III. p. 174.

Ty pe in British Museum.

H a b._Sudest Island, Louisiades (Forbes, Kowald and Belford).

45. G. millicente, Cox, 1871.

I 11 u s$^{\text {n. }-P . Z . S . ~ 1871, ~ p l . ~ 34, ~ f i g s . ~ 2-2 a . ~}$

D es c r ${ }^{\text {n. }}$-L.c. p. 323 : l.c. 1873 , p. 566.

Ty pe in the Cox Collection.

H a b.-Louisiades (Cox).

This is intermediate between louisiadensis and rollsianus, and is probably entitled to rank as a distinct species. The exact island inhabited by it is still unknown.

46. G. Rollsianus, E. A. Smith, 1887.

I 11 u s$^{n}$-Ann. Mag. Nat. Hist. (5), xix. pl. 15, fig. 3.

D e s c r ${ }^{\mathrm{n}}$ - L.c. (5). xIx. 423. 
Ty pe in British Museum.

Hab.-Not South Cape Island (Rolls), but Seymour Bay, Fergusson Island (Hedley). As Rolls and Goldie landed in Seymour Bay, I have no doubt that they collected the type exactly where I found the species several years afterwards. I make the above correction with the more confidence since $I$ have searched South Cape in vain for it. It is interesting to note that both $G$. rollsianus and $P$. brazierce, which I also gathered at Seymour Bay, find their allies among the distant Louisiades and not with the molluses of the nearer mainland.

Animal slender; colour entirely white in one specimen, bluishwhite in another; tentacles long, slender, tapering, bases wide apart. Observed crawling upon the trunks of trees.

47. G. albocarinatus, E. A. Smith, 1887.

Ill u sn.-Ann. Mag. Nat. Hist. (5), xix. pl. 15, fig. 12.

Des c r ${ }^{\text {n. }-L . c . ~ p . ~} 422$; l.c. (6) vir. 137.

Ty $\mathrm{p}$ e in British Museum.

Ha b.-Woodlark Island (Dr. Rabe fide Brazier); another recorded but probably erroneous locality is South Cape Island (Goldie).

48. G. тhomsoni, E. A. Smith, 1889.

I $11 \mathrm{u} \mathrm{s}^{\mathrm{n}}$-A Ann. Mag. Nat. Hist. (6), Iv. pl. 13, figs. 12, 13.

D es c r ${ }^{\text {n. }}$ - L.c. (6), Iv. 202.

$\mathrm{T}$ y $\mathrm{p}$ e in British Museum.

var. a.

H a b._St. Aignan, Louisiades (Thomson, Kowald and Belford).

49. G. woodlarkianus, Souverbie, 1863.

Ill u s${ }^{\text {n. }}$-Journ. de Conch. xI. pl. 5, fig. 2.

Des c r ${ }^{\text {n. }}$ LL.c. pp. 76 and 172 ; Mon. Hel. Viv. v. p. 271 ; Ann. Mag. Nat. Hist. (6), vir. 137.

Ty p e in Bordeaux Museum. 
H a b.-Woodlark Island (French Missionaries, Kowald and Belford, Dr. Rabe fide Brazier); Normanby Island (Dr. Rabe), the latter a doubtful locality.

50. G. trobriandensis, n.sp.

(Plate xI., fig. 28.)

Shell imperforate, trochiform, thin, translucent, keeled at the periphery, keel becoming obsolete latterly ; colour white, encircled by seven chestnut bands, four above and three below the periphery, these bands are very variable, each or all may disappear or coalesce, when absent a translucent band marks the site, the bands fade away on the penultirnate whorl, occasionally as in allied species opaque alternate with translucent dashes radiating from the suture, peristome from the insertion of the right margin to the centre of the base an intense black; whorls $4 \frac{1}{2}$, convex, last contracted ; sculpture, obliquely finely striated and finely granulated; apex obtuse, embryonic whorls distinct, $1 \frac{1}{2}$; suture impressed; base slightly convex ; aperture oblique, scarcely descending, peristome expanded and reflected, right margin sinuate, columellar margin straight bearing above a small tubercle, margins connected by a thin, transparent, microscopically granulated callus. Diam. maj. 24, min. 18 , alt. $16 \mathrm{~mm}$.

Ty pe in Queensland Museum.

$\mathrm{H}$ a b.-Trobriand Islands (Kowald and Belford); on trees; abundant.

The local representative of the $G$. louisiadensis group.

51. G. taumantias, Tapparone-Canefri, 1883.

I 11 u s$^{\mathrm{n}}{ }^{\mathrm{n}}$-Ann. Mus. Gen. xix. pl. 3, figs. 13, 14.

D e s c r ${ }^{\text {n. }}$-L.c. p. 141.

A n a t._L.c. pl. 6, fig. 4, pl. 9, figs. 16, 18.

Ty p e in Genoa Museum.

vars. alpha and beta. 
Hab.-Katow River (D'Albertis); Fly River (D'Albertis, Froggatt, Macgregor).

\section{var. cingulatus, var.nov.}

Yellowish-white encircled by a single brown peripheral band margined beneath by an opaque white line.

Ty pe in Queensland Museum.

H a b.-Village of Aipiana, St. Joseph River (Hedley).

52. G. tomasinellianus, Tapparone-Canefri, 1883.

I 11 u s$^{\text {n. }}$-Ann. Mus. Gen. xıx. pi. 4, fig. 1, pl. 5, fig. 1.

Des c r ${ }^{\text {n. }}$-L.c. p. 148.

A n a t.-L.c. p. 7, fig. 3, pl. 8, figs. 6, 12 .

Ty p e in Genoa Museum.

var. alpha.

H a b.-Fly River (D'Albertis, Froggatt); 400 miles up the Fly (Macgregor); Katow River (D'Albertis).

var. azonatus, var.nov.

Bandless, entirely yellow.

Ty pe in Australian Museum.

H a b.-Douglas River (Bevan).

53. G Ridibundus, Tapparone-Canefri, 1883.

I $11 \mathrm{u} \mathrm{s}^{\mathrm{n}}$-Ann. Mus. Gen. xix. pl. 3, figs. 10, 11.

D e s c rn. -L.c. p. 142.

A n a t.-L.c. pl. 6, fig. 5, pl. 8, fig. 17 .

Ty pe in Genoa Museum.

H a b._Fly River (D'Albertis).

54. G. meditatus, Tapparone-Canefri, 1883.

I $11 \mathrm{u} \mathrm{s}^{\mathrm{n}}$ - Ann. Mus. Gen. xix. pl. 3, fig. 15 .

Des cr n. -L.c. p. 144. 
A n a t.-L.c. pl. 6 , fig. 6 .

Ty p e in Genoa Museum.

H a b.-Katow River (D'Albertis).

55. G. GeSTroI, Tapparone-Canefri, 1883.

Ill u sn.-Ann. Mus. Gen. xix. pl. 4, fig. 3, pl. 5, fig. 3 .

Des c rn.-L.c. p. 150.

A n a t.--L.c. pl. 7, fig. 2, pl. 8, figs. 5, 14.

Ty pe in Genoa Museum.

var. alpha.

H a b.-Fly River (D'Albertis).

56. G. Siculus, Brazier, 1876.

De s c rn.-P.L.S.N.S.W. (1), I. 106 ; Ann. Mus. Gen. xix. p. 153.

Ty pe in Macleay Museum.

H a b.-Katow River (Brazier).

Mr. Brazier informs me that this species resembles the Solomon Island shells ambrosia, Angas, and mendana, Angas, the latter particularly in coloration.

57. G. Braziere, Brazier, 1876.

I $11 \mathrm{u} \mathrm{s}^{\mathrm{n}}$-Ann. Mus. Gen. xix. pl. 4, fig. 2, pl. 5, fig. 2.

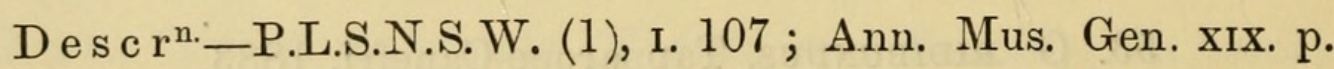
152.

A n a t.-L.c. xix. pl. 7, fig. 1, pl. 8, figs. 7, 13.

Ty pe in Macleay Museum.

H a b.-Yule Island (Brazier) ; St. Joseph, Doura (Hedley).

58. G. lacteolatus, E. A. Smith, 1887.

I 11 u s. ${ }^{\text {n. }}$ Ann, Mag. Nat. Hist. (5), xIx. pl. 15, fig. 9.

D e s c rn.-L.c. (5), xIx. 420 .

Ty pe in British Museum.

$\mathrm{H}$ a b. - Foot of Owen Stanley Range (Goldie fide Brazier). 
59. G. gurgusti, Cox, 1880.

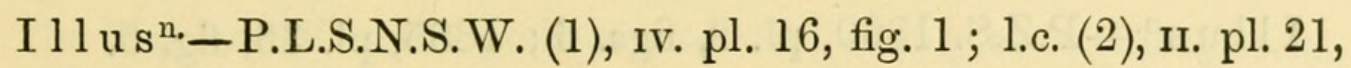
figs. 3,4 .

Des c r ${ }^{\text {n. }}$-l.c. (1), Iv. 114 .

Ty pe in Australian Museum.

H a b.-Rossel Island, Louisiades (Hovell).

60. G. chapmani, Cox, 1880.

S y n.-coraliolabris, Smith, 1887.

I 11 u s$^{\text {n. }}$-P.L.S.N.S.W. (1), IV. pl. 16, fig, 2 ; l.c. (2), II. pl. 21 , figs. 10, 11 ; Ann. Mag. Nat. Hist. (5), xıx., pl. 15, fig. 4 ; Tryon, Man. (2), vi. pl. 17, fig. 13.

D e s c r ${ }^{\text {n. }}$-P.L.S.N.S.W. (1), Iv. 115 ; Ann. Mag. Nat. Hist. (5), xI. 419 ; l.c. (6), IV. 201.

Ty pe in Australian Museum.

H a b.-Rossel Island, Louisiades (Hovell, Thomson).

61. G. canovari, Tapparone-Canefri, 1883.

Ill u s${ }^{\mathrm{n}} \cdot-$ Ann. Mus. Gen. xix. pl. 3, fig. 6.

D e s c rn.-L.c. xIx. p. 131.

Ty p e in Genoa Museum.

H a b.-Fly River (D'Albertis) ; Observation Point, Fly River (Froggatt).

62. G. BOyeri, Fischer and Bernardi, 1857.

Ill u sn.-Journ. de Conch. v. pl. 9, figs. 8, 9.

Des c rn.-L.c. v. p. 297 ; Ann. Mag. Nat. Hist. (6), vil. 137 ; Mon. Hel. Viv. Iv. p. 201.

$\mathrm{T}$ y pe in collection of Journ. de Conch.

H a b.-Not Admiralty Island (F. \& B.), nor Louisiades (Angas fide Pfeiffer), but Woodlark Island (Dr. Rabe fide Brazier, Kowald and Belford). 
63. $\dagger$ G. Dampieri, Angas, 1869.

I $11 \mathrm{u} \mathrm{s}^{\mathrm{n}}$-P.Z.S. 1869, pl. 2, figs. $6 ; 1885$, pl. 36, fig. 5 .

D e s c rn. -L.c. 1869 , p. 47 ; Mon. Hel. Viv. vir. p. 310.

Tyре (?).

$\mathrm{H}$ a b.-Louisiade Islands (Angas)?.

No definite locality in the Louisiades is known for this shell, and since a variety is recorded from the Solomons by Smith (P.Z.S. 1885, p. 592), it is most probable that the type was derived from thence.

Recorded from the province in error.

G. (?) Coniformis, Férusac.

Jahrb. deutsche mal. Gesell. 1880, p. 15.

Louisiade Archipelago (Kobelt, l.c.).

G. HORDERI, Sowerby.

P.Z.S. 1889 , pl. 56 , fig. 1, p. 577 .

May belong to this province; but the author neglects to say where or by whom it was collected.

\section{Cochlostyla papuensis, n.sp.}

(Plate xII., fig. 30.)

Shell globosely conical, imperforate, solid; colour, the hydrophanous epidermis when wet or oiled is of a rich chocolate colour ; when dry, a pale yellowish-brown crossed by numerous narrow spiral brown lines; deprived of the epidermis the shell is a pale yellow, with a brown sub-sutural band, first two whorls purpleblue, interior of shell lustrous pale blue, peristome brown ; whorls $5 \frac{1}{2}$, convex, regularly increasing, last $\frac{5}{7}$ ths of total length ; sculpture, entire shell finely obliquely striated and encircled by microscopic close regular raised lines; apex obtuse, embryonic whorls $1 \frac{1}{2}$; suture impressed, margined; aperture oblique, ovate lunate, peristome slightly reflected, a thin semi-transparent callus 
extends over the axis and curves up to the insertion of the right margin. Alt. 55 , breadth $38 \mathrm{~mm}$.

The Macleay Museum possesses several examples of this species, purchased from Mr. Goldie, who collected them in British New Guinea. Considerable difference in size and form exists between these specimens, none of which are in a good state of preservation. One old and worn shell exhibits on the inner side of the columella a tubercle $10 \mathrm{~mm}$. long and $2 \mathrm{~mm}$. wide. Whether this be a distinct species, the adult form, or merely a variety of the species described above, requires further material to decide.

65. Calycia isseliana, Tapparone-Canefri, 1883.

Ill u s" ${ }^{n}$-Ann. Mus. Gen. xix. p. 101, figs. b, c.

D e s c rn.-L.c.

Type in Genoa Museum.

H a b.-Katow River (D'Albertis).

The systematic position of this molluse is uncertain.

66. †Bulimus macleayi, Brazier, 1876.

S y n.-beddomei, Brazier, MSS.

I 11 u s" ${ }^{n}$-Ann. Mus. Gen. xIx. pl. 2, figs. 16, 17.

D e s c rn.-P.L.S.N.S.W. (1), I. 108 ; l.c. (1), Iv. 395 ; Ann. Mus. Gen. xix. p. 104 ; Trans. Roy. Soc. S. Australia, v. p. 50.

Type in Macleay Museum.

H a b.-Yule Island (Brazier, D'Albertis).

This species ranges south to North Queensland and west to Port Darwin.

67. Partula similaris, Hartman, 1886.

Ill u s${ }^{\mathrm{n}}$-Proc. Acad. N.S. Phil. 1886, pl. 2, fig. 1.

D e s c rn.-L.c. p. 30 .

T у р е.-(?)

H a b. -Woodlark Island (Brazier). 
68. P. woodlarkiana, Hartman, 1886.

Ill u s ${ }^{\text {n. }}$-Proc. Acad. N.S. Phil. 1886, pl. 2, fig. 8.

Deser ${ }^{\text {n. }}$-L.c. p. 33.

Ty pe-(?).

$\mathrm{H}$ a b.-Woodlark Island (Brazier).

After examining the figures and descriptions of these two species, I am unable to grasp any specific distinction between them. Specimens collected at the Woodlarks by Messrs. Kowald and Belford during the eruise of the "Merrie England" in 1890 are referable to both or either forms.

\section{P. occidentalis, n.sp.}

(Plate xir., fig. 31.)

Shell dextral, ovate elongate, thin and translucent; colour (?) ; whorls 5, rounded, last a little flattened below the suture; sculpture everywhere encircled by close sharply impressed spiral lines, which are decussated by oblique irregular lines of growth, at the intersection the former are sometimes distorted by the latter; spire slender, elongate, a quarter of total length; apex domeshaped, half of first whorl embryonic; suture impressed; umbilicus small, deep, compressed; aperture roundly ovate, scarcely oblique, lip moderately reflected and expanded, margins of the peristome connected by a thick callus. Length 19, breadth 10 , length of aperture 9, breadth $6 \mathrm{~mm}$. ; length 17 , breadth 10 , length of aperture 9 , breadth $7 \mathrm{~mm}$.

Ty pe in Queensland Museum.

$\mathrm{Hab}$.-On the ground under bushes upon Samarai Island I collected two dead shells of this species.

The two Partulie described by Lesson have, as Tapparone remarks, a doubtful claim to Papuan soil, and, omitting these, the above species is the first described from New Guinea proper.

70. †Stenogyra subula, Pfeiffer, 1839.

Syn.-juncea, Gould, 1846 ; tuckeri, Pfr. 1846 ; octonoides, D’Orb. 1841 ; procera, Adams, 1845 ; walli, Cox, 1864 ; upolensis, 
Mousson, 1865 ; panayensis, Pfeiffer, 1846 ; diaphana, Gassies, 1859 ; souverbiana, Gassies, 1863; artensis, Gassies, 1866 ; novemgyrata, Mousson, 1870 ; gyrata, Mousson, 1885.

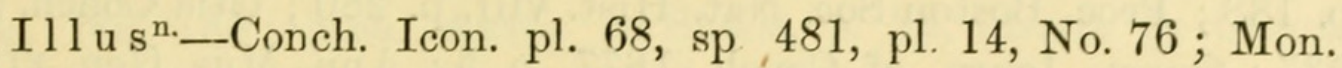
Austr. L. Shells, pl. 13, fig. 9 ; Gould, Expl. Exped. Shells, fig. 87 Phil. Is. Land Moll. III. pl. 8, figs. 14, 15 ; Martens, Ostas. Zool. II. pl. 22, fig. 8 ; Faune Nouv. Caled. pt. 1, pl. 2, fig. 5 ; Journ. de Conch. 1863, pl. xıv. fig. 6 ; \&c., \&c.

D e s c rn.-Wiegm. Arch. I. $3 \check{2} 2$; Moll. Cub. I. 177 ; P.Z.S. 1846, p. 30 , 1887, p. 185 ; Mon. Hel. Viv. II. p. 158 ; Mon. Austr. L. Shells, p. 69 ; Proc. Bost. Soc. Nat. Hist. II. p. 35, 191 ; Journ. de Conch. 1859, p. 370 ; Faune Nouv. Caled. pt. 1, p. 52 ; \&c., \&c.

A n a t.-Reis. Phil. Land Moll. III. pl. xI. figs. 17, 21.

$\mathrm{T}$ y $\mathrm{pe}$ in British Museum.

H a b.-St. Joseph River, Port Moresby, Samarai, and Milne Bay (Hedley).

It is remarkable that this common and ubiquitous mollusc has not been previously recorded from the New Guinea mainland.

71. Tornatellina terestris, Brazier, 1876.

De s c r ${ }^{\text {n. }}$-P.L.S.N.S.W. (1), I. 109 ; Ann. Mus. Gen. xix. p. 102.

Ty pe in Macleay Museum.

$\mathrm{H}$ a b.-Yule Island (Brazier).

72. †Pupa Pedicula, Shuttleworth, 1852.

S y n.- artensis, Montrouzier, 1859; nitens, Pease, 1860; nacca, Gould, 1862 ; hyalina, Zelebor, 1868 ; macdonnelli, Brazier, 1875 ; recondita, Tapparone-Canefri, 1883 ; samoensis, Schmeltz, MSS.

Illusn. -Journ. de Conch. vil. pl. 8, fig. 4 ; Faune Nouv. Caled. pt. 1, pl. 6, fig. 21 ; P.Z.S. 1874, pl. 83, figs. 22, 23 ; Ann. Mus. Gen. XIX. pl. 2, figs. 3, 4. 
D e s c rn. -Bern. Mittheil. 1852, p. 296 ; Mon. Hel. Viv. III. p. 557, vi. pp. 329, 330, 335 ; Journ. de Conch. vir. p. 288 ; Faune Nouv. Caled. pt. 1, p. 54 ; P.Z.S. 1860 , p. 439 , 1874 , p. 669,1887 , p. 188 ; Proc. Boston Soc. Nat. Hist. viII. p. 280 ; Otia Conch. p. 237 ; Quart. Journ. of Conch. 1877, p. 5 ; Ann. Mus. Gen. xix. p. 106.

T у р е-(?).

H a b.-Mita, Milne Bay, Samarai and Loggia Islands (Hedley).

73. †Succinea simplex, Pfeiffer, 1854.

(Plate Xì., fig. 32.)

Des c r ${ }^{\text {n. }}$-P.Z.S. 1854 , p. 123, 1885, p. 595 ; Mon. Hel. Viv. Iv. p. 813 .

Ty pe in British Museum.

A species of Succinea occurs in abundance upon the stems of taro leaves in the hill gardens above Mita village, Milne Bay, specimens of which answer fairly well to the description Pfeiffer gives of $S$. simplex. Being unable to compare my specimens with a figure or authentic named examples, I refer them to the Solomon Island species with some hesitation.

74. †Truncatella valida, Pfeiffer, 1846.

S y n.-vitiana, Gould, 1847 ; vitiacea, Mousson, 1865 ; conspicua, Bronn.

Ill u s${ }^{\text {n. }}$-Kuster, Conch. Cab. ed. 2, pl. 2, fig. 7, 8, 19, 20, 21, 23 ; Cox, Mon. Austr. L. Shells, pl. 20, figs. 21, 21a, 21 b.

D es c r ${ }^{\text {. }}$ ZZeitschr. Malak. 1846, p. 182 ; Mon. Auric. I. p. 184 ; Conch. Cab. p. 11 ; Proc. Bost. Soc. Nat. Hist. II. p. 208 ; P.Z.S. 1887 , p. 299 ; \&c.. \&c.

$\mathrm{T}$ y $\mathrm{p}$ e in British Museum.

H a b.-Port Moresby, Milne Bay, Samarai (Hedley).

75. $\dagger$ T. ceylanica. Pfeiffer, 1856.

S y n.-teres, Pfr. 1856 ; semicostata, Montrouzier, 1862 ; cerea, Gassies; nitida, Gassies. 
I 11 u s$^{\text {n. }}$-Mon. Austr. L. Shells, pl. 15, figs. 9, 9a, 9b ; Journ. de Conch. 1862, pl. 9, fig. 10 ; Faune Nouv. Caled. pl. 8, fig. 2.

D e s c rn-P.Z.S. 1856 , p. 336 ; 1887, 300 ; Mon. Auric. I. pp. 186, 188 ; Mon. Austr. L. Shells, p. 92; Journ. de Conch. 1862, p. 243 ; Faune Nouv. Caled. p. 73 ; \&c., \&c.

$\mathrm{T}$ y $\mathrm{p}$ e in British Museum.

H a b.-Port Moresby (Hedley).

The Truncatellæ are characteristic of an assemblage of forms which may be termed the land littoral fauna, other members being Stenogyra tuckeri, Pupa pedicula, Pythia scarabceus, and perhaps, Conulus starkei, and C. russelli. This littoral fauna always inhabits, but is not invariably confined to, the neighbourhood of the sea beaches. The smallest islands which possess any life at all are usually stocked by these forms, which appear to range from Ceylon in the west to the Sandwich Islands in the east, and to be limited north and south by the tropics. Within these bounds they are associated with many widely different faunæ.

\section{OMPHALOTROPIS BRAZIERI, n.sp.}

(Plate xir., fig. 33.)

Shell acutely ovate ; colour corneous ; whorls.5, convex, gradually increasing; sculpture, regular oblique striæ, last whorl encircled at the periphery by a strong keel; suture impressed; spire conical, a quarter of total length, apex acute ; base flattened ; umbilicus small, angled at the margin; aperture oblique, subcircular, angled above, peristome double, callus on body whorl thin. Operculum not observed. Length 5, breadth $3 \mathrm{~mm}$.

T y p e in Queensland Museum.

$\mathrm{H}$ a b. - South shore of Milne Bay and Basilaki Island (Hedley); one example collected at each locality.

\section{O. PROTRACTA, n.sp.}

(Plate XII., fig. 34.)

Shell elevated conical, thin, turreted, glossy; colour dark corneous; whorls 6 , gradually increasing, rounded, rather flattened 


\section{THE LAND MOLLUSCAN FAUNA OF BRITISH NEW GUINEA,}

beneath the suture, last angled at the periphery; sculpture faint oblique striæ ; sutnre impressed ; spire produced, one-third of total length ; base rounded ; umbilicus ample, funnel-shaped, angled at the margin ; aperture vertical, subcircular, angled above, peristome slightly thickened and scarcely reflected, callus on the body whorl thin. Operculum not observed. Length $3 \frac{1}{2}$, breadth $2 \mathrm{~mm}$.

Ty p e in Queensland Museum.

H a b.-Mission Hill, Upper St. Joseph River (Hedley); two examples under fallen timber in dense jungle.

\section{Bellardiella minor, n.sp.}

(Plate xII., fig. 35.)

Shell imperforate, oblong; colour ?; whorls 6 , penultimate and antepenultimate bulging above the suture, last rather flattened on the periphery and more so on the base ; spire inclined to the right, less than half of total length ; apex acute, first two whorls devoid of sculpture appearing embryonic; sculpture, close oblique, sharp, thread-like riblets ; suture impressed ; aperture circular, peristome thick, expanded and briefly reflected, body-whorl overlaid with a tlick callus, upper canal obsolete, lower one converted into a closed circum-umbilical tube, whose orifice is, when adult, quite outside the peristome, when immature the tube communicates with the adjacent whorl by a narrow slit, whose position is later marked by a scar. Length 14, breadth 9 , diam. of aperture $4 \mathrm{~mm}$.

Ty $\mathrm{p}$ e in Queensland Museum.

$\mathrm{H}$ a b.-Mission Hill, near the village of Ngauauni, upon the upper waters of the St. Joseph ; I found several dead specimens in a banana garden.

The arrangement of the lateral canal resembles that of Pupinella minor and P. macgregori.

79. Pupinella macgregori, E. A. Smith, 1889.

Ill $\mathrm{u} \mathrm{s}^{\text {n. }}$-Ann. Mag Nat. Hist. (6), Iv. pl. 13, fig. 1, 2.

D e s c rn. -L.c. (6), Iv. 205. 
Ty pe in British Museum.

H a b.-CRossel Island, Louisiades (Thomson, Kowald and Belford).

The Louisiade Pupinellæ appear to fall into three natural groups: (a) comprising $P$. macgregori and $P$. minor, in which the lateral canal is produced into a tube around the umbilical region; (b) containing $P$. grandis, $P$. angasi, $P$. smithi, $P$. moulinsiana, and $P$.rosseliana, in which the canal merely notches the columellar margin, the five in the order named being a graduated series whose notch is completely cut, half cut, and scarcely indented; they form an easy transition to (c) P. brazierce, in which the notch is absent.

80. P. minor, E. A. Smith, 1889.

I 11 u s$^{\text {n. }}$-Ann. Mag. Nat. Hist. (6), Iv. pl. 13, figs. 7, 8.

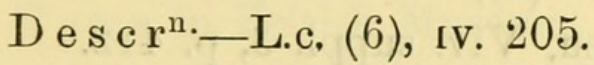

T y p e in British Museum.

H a b.-Rossel Island (Thomson, Kowald and Belford).

The single specimen, the second known to science, collected by the latter is in a good state of preservation. The colour is a dark red ; the sculpture differs remarkably from that of its allies, their coarse malleations being entirely absent, instead are developed close, raised, oblique, sinuate hair lines. The lip and callus are, under the lens, delicately granulated.

\section{P. Grandis, Forbes, 1852.}

S y n.-forbesi, Pfeiffer, 1852.

I 11 u s".-Voy. "Rattlesnake," A ppend. pl. 2, figs. 10, a, b, c, d ; Pfeiffer, Conch. Cab. ed. 2, pl. 31, figs. 19, 20 ; Conch. Icon. Pupinidæ, fig. 4.

D e s c r" -Voy. " Rattlesnake," II. p. 380 ; Mon. Pneu. Viv. I. p. 140.

Type in British Museum.

H a b..-Sudest Island (Forbes, Kowald and Belford). 
104 THE LAND MOLLUSCAN FAUNA OF BRITISH NEW GUINEA,

82. P. angasi, Brazier, 1875.

S y n.-louisiadensis, Smith, 1889.

Ill $\mathrm{u} \mathrm{s}^{\mathrm{n}}$ - Ann. Mag. Nat. Hist. (6), Iv. pl. 13, figs. 3, 4.

D e s c r ._P.L.S.N.S.W. (1), I. 5 ; Ann. Mag. Nat. Hist. (6), IV. 204, and (6), viI. 135 .

Ty p e in British Museum.

H a b.-Rossel Island (Thomson).

83. P. sмiтhi, Brazier, 1891.

Syn.-angasi, H. Adams, 1875 ; grandis var. minor, Cox, 1873.

I $11 \mathrm{u} \mathrm{s}^{\mathrm{n}}$-P.Z.S. 1875, pl. 45, figs. 2, 2a.

D e s c rn._Ann. Mag. Nat. Hist. (6), vir. 136 ; P.Z.S. 1873, p. 567 ; l.c. 1875 , p. 389 ; Mon. Pneu. Viv. suppl. 3, p. 412.

Ty pe in British Museum.

H a b.-Louisiade Archipelago (Adams, \&c.).

The volume containing Adams' diagnosis of angasi, No. 2, bears the date October 1st, 1875, whereas Brazier's description of angasi, No. 1, appeared in the first twenty pages of these Proceedings, which were printed separately and published May, 1875, giving the Australian naturalist the priority of publication by four months. Until the present year, all authors who have written upon Papuan conchology appear to have overlooked Brazier's account.

84. P. moulinsiana, Fischer and Bernadi, 1857.

S yn.-intermedia, Angas, MSS. ; leucostoma, Montrouzier, 1857.

I $11 \mathrm{u} \mathrm{s}^{\mathrm{n}}$._Journ. de Conch. v. pl. 9, figs. 6, 7 ; Thes. Conch. III. pl. 265 , fig. 36 .

D es c r ${ }^{\mathrm{n}}$ - - Journ. de Conch. v. 299 ; xIx. 183; Essai sur la Faune de Woodlark, 136 ; Mon. Pneu. Viv. II. 93 ; P.Z.S. 1871, 586. 
$\mathrm{T}$ y p e in collection of the Journ. de Conch.

H a b.-Woodlark Island (Montrouzier).

85. P. rosseliana, E. A. Smith, 1889.

Ill u s${ }^{n}$ - Ann Mag. Nat. Hist. (6), Iv. pl. 13, figs. 5, 6, 6a.

D e s c rn. -L.c. (6), iv. 205.

Ty pe in British Museum.

H a b.--Rossel Island (Thomson, Kowald and Belford).

86. P. braziere, E. A. Smith, 1887.

S y n.-typica, Brazier, MSS.

Ill u s s. -Ann. Mag. Nat. Hist. (5), xix. pl. 15, fig. 15.

D e s c r ${ }^{\text {n. }}$ L.c. (5), XIx. 424, and (6), viı. 136.

$\mathrm{T} y \mathrm{pe}$ in British Museum.

Hab.-Seymour Bay, Fergusson Island (Goldie, Hedley); Cape Pierson, Normanby Island (Dr. Rabe fide Brazier).

Found alive on the ground, under logs of wood.

var. aignanensis, var.nov.

Larger and more widely umbilicated than the type. Length $28 \mathrm{~mm}$.

T y $\mathrm{pe}$ in Queensland Museum.

H a b.-St. Aignan, Louisiades (Kowald and Belford); one dead specimen.

87. P. Crossei, Brazier, 1877.

Ill u sn.-Ann. Mus. Gen. xix. pl. 10, figs. 18, 19.

Descrn.-P.L.S.N.S.W. (1), I. 111 ; Ann. Mus. Gen, xix. 267.

Ty pe in Macleay Museum.

$\mathrm{H}$ a b.-Yule Island (Brazier).

I am indebted-to Mr. John Brazier, F.L.S., C.M.Z.S., for the following description :- 
88. "P. tapparonei, Brazier, n.sp.

(Plate xII., fig. 36.)

"Shell shortly rimate, oblong-ovate, rather solid, regularly and obliquely finely striate, light brown; spire gradually tapering towards the rather pointed apex; whorls 6 , four upper convex, the fifth slightly flattened on the side of the mouth, the last much narrower; aperture vertical, circular; peristome whitish, thickened, expanded and reflected, with two channels; one very small, narrow, and deep at the insertion of the iight margin, the second shallow and surrounded with thick callus between the arcuate body-margin and the left or columellar. Length of largest specimen 18, breadth 8 ; length of smallest specimen 14, breadth $7 \mathrm{~mm}$.

"Ty pe in Australian Museum.

“ H a b.-Fly River, British New Guinea (Froggatt).

"Two specimens - one living, the other dead-of this very rare species were collected by Mr. W. W. Froggatt when he went in the Geographical Society's Expedition of 1885 to the Fly River.

"Some dead and worn specimens of this same species were found by Signor L. M. D'Albertis on the Fly River; they are mentioned by Dr. C. Tapparone-Canefri in his valuable paper on the 'Fauna Malacologica Della Nuova Guinea,' 1883, p. 268. I take great pleasure in naming the species after my valued friend and correspondent, Dr. C. Tapparone-Canefri."

\section{Pupina ovalis, n.sp.}

(Plate xiI., fig. 37.)

Shell ovate-oblong, smooth and extremely glossy; colour reddish-horn; whorls $5 \frac{1}{2}$, slightly convex; spire shortly ovate, $1 \frac{1}{3}$ of total length; apex obtuse; suture margined by a callus, faintly impressed; aperture subvertical, circular, anterior canal deep and narrow, parietal lamella a stout rib curving from one canal to the other, columella flat, widely dilated, deeply notched 
by the lateral canal, peristome thickened slightly and reflected. Length 8, breadth $6 \mathrm{~mm}$.

Ty pe in Queensland Museum.

H a b.-Mita, Milne Bay (Hedley); six specimens, under logs in dense jungle on hillsides; rare.

90. P. GIBBA, n.sp.

(Plate xir., fig. 38.)

Shell minute, oblong, smooth and extremely glossy; colour pale corneous; whorls 5, last convex, rather flattened below the suture, penultimate gibbose, tumid ; spire $\frac{1}{4}$ of total length ; apex obtuse; suture margined by a callus, impressed; aperture subvertical, circular, anterior canal distinct, lateral, a narrow cleft across the peristome developing outside the lip, a circular orifice, parietal lamella obscure, peristome slightly thickened and reflected. Length 4 , breadth $2 \mathrm{~mm}$.

Ty pe in Queensland Museum.

Hab.-Mission Hill, Ngauauni, Upper St. Joseph River (Hedley); four specimens under logs in jungle upon the hillside.

\section{Diplommatina symmetrica, n.sp.}

(Plate xII., fig. 39.)

Shell dextral, rimate, elongate, ovate, turreted, thin, translucent; colour reddish-corneous; whorls 7, rounded, increasing regularly as far as the antepenultimate, which equals its successor in breadth; sculpture, closely obliquely ribbed by thin white erect lamellæ, not continuous, projecting at the shoulder, minutely spirally striated between the ribs; suture deeply impressed; apex obtuse ; aperture subvertical, circular, columellar margin straight, bearing a moderate-sized internal tubercle, peristome double, greatly expanded round its entire margin, forming a broad callus upon the penultimate whorl. Alt. $3 \frac{1}{2}$, breadth $1 \frac{1}{2} \mathrm{~mm}$.

T y p e in Queensland Museum. 
108 The LAND MOLLUSCAN FAUNa OF BRITISH NEW GUINEA,

$\mathrm{H} \mathrm{a} \mathrm{b}$-Basilaki (formerly called Moresby) Island (Hedley); found abundantly upon decaying leaves of Pandanus upon a steep hill side.

92. Cyclotropis papuensis, Tapparone-Canefri, 1883.

Ill u s ${ }^{\text {n. }}-A n n$. Mus. Gen. xIx. pl. 10, figs. 22, 23.

D e s c r ${ }^{\text {n. }}$-L.c. xix. p. 279.

Ty pe in Genoa Museum.

H a b.-Fly River (D'Albertis).

93. Cyclotus poirieri, Tapparone-Canefri, 1883.

I $11 \mathrm{u} \mathrm{s}^{\mathrm{n}}$-Ann. Mus. Gen. xIx. pl. 10, figs. 6, 7 .

Des c r ${ }^{\text {n. }}$-L.c. xIx. 254 .

Ty pe in Genoa Museum.

H a b. -Fly River (D'Albertis).

94. C. tristis, Tapparone-Canefri, 1883.

Ill u s${ }^{n}$. Ann. Mus. Gen. xIx. pl. 10, figs. 4, 5.

D e s c r ${ }^{\text {n. }}$-L.c. xIx. 255.

Ty pe in Genoa Museum.

H a b._Fly River (D'Albertis, Froggatt).

95. C. HORRIDUs, n.sp.

(Plate xII. bis, fig. 40.)

Shell depressed, turbinate, widely and perspectively umbilicated; colour fulvous; whorls 5, rapidly increasing, rounded, last descending at the aperture; suture deeply impressed; apex acute; sculpture, numerous close regular fine spiral lyræ, crossed by longitudinal lines of small stiff epidermal bristles; aperture scarcely oblique, rounded, subangled above, peristome continuous, thickened, straight. Operculum externally concave, white, calcareous, subcircular, 5-whorled, whorls margined within by a deep furrow. Diam. maj. 9, min. 7, alt. $7 \mathrm{~mm}$.

$\mathrm{T}$ y $\mathrm{pe}$ in Queensland Museum. 
H a b.-Milne Bay, Mita and South shore (Hedley); twelve dead and immature specimens, in jungle under logs. The best preserved but immature specimen which furnished the figure had not attained the adult peristome.

\section{C. KoWALDI, n.sp. \\ (Plate xII. bis, fig. 41.)}

Shell turbinate, openly umbilicated; colour fulvous, faintly radiately painted with dark brown; whorls $5 \frac{1}{2}$, rounded, obscurely bicarinate; suture channelled; apex mammillate; sculpture, the body whorl is encircled by about 15 lyræ, two of which, one at and one above the periphery, attain more prominence developing into keels, within the umbilical funnel the lyræ are closer, smaller and more numerous, the lyræ are decussated by costæ at the junction of which an epidermal bristle is generally developed; peristome in the individual observed thin and therefore probably juvenile. Operculum not received. Diam. maj. 9, min. 7, alt. $6 \mathrm{~mm}$.

Ty pe in Queensland Museum.

$\mathrm{H}$ a b. - Sudest Island, Louisiades (Kowald and Belford); one specimen.

$$
\begin{aligned}
& \text { 97. C. BELfordi, n.sp. } \\
& \text { (Plate xir. bis, fig. } 42 . \text { ) }
\end{aligned}
$$

Shell trochiform, narrowly umbilicated; colour fulvous-brown; whorls $4 \frac{1}{2}$ (juv. ?), acutely carinated; suture channelled; apex mammillate; sculpture, spiral lyræ decussating radiate costæ, the acute carina of the periphery bearing a single row of long bristles, peristome sharp (juvenile?). Operculum wanting. Diam. maj. $4 \frac{1}{2}$, min. 4 , alt. $4 \frac{1}{2} \mathrm{~mm}$.

$\mathrm{T}$ y $\mathrm{p}$ e in Queensland Museum.

H a b.-Mita, Milne Bay (Hedley); two specimens.

I describe these Cycloti from imperfect material with some hesitation; none have been before recorded from this neighbourhood, and I trust that their marked characteristics will enable 
subsequent observers to recognise them. The two latter species are named after Messrs. Charles Kowald and George Belford whose collections have been so frequently referred to in preceding pages.

98. †Leptopoma vitreum, Lesson, 1830.

Syn.-luteum, Quoy and Gaimard, 1832 ; nitidum, Sowerby, 1843.

Illu s".-Voy. "Coquille," Moll. pl. 13, figs. 6, 6'; Voy. "Astrolabe," Moll. pl. 12, figs. 11, 12, 13, 14; Sow. Thes. Conch. I. pl. 29, figs. 225, 226, 227 ; Reeve, Conch. Syst. pl. 183, fig. 2 ; Reeve, Conch. Icon. xII. pl. 3, fig. 15a, b, pl. 6, fig. 32; Chem. Conch. Cab. ed. 2, pl. 16, figs. 10, 16, 17, 18 ; Adams, Gen. Moll. pl. 85, figs. 7, 7a, 7b, Chenu, Man. Conch. figs. 3602, 3603; Cox, Aust. L. Shells, pl. 16, figs. 2, 2a, 3 ; Tryon, Struct. Syst. Conch, II. pl. 76, figs. 3,4 .

D e s c r"-Voy. "Coquille," Zool. ir. 346 ; Voy. "Astrolabe," Zool. II. 180 ; P.Z.S. 1843, p. 60 ; Lamk. An. s. Vert. 2 ed. viII. 367 ; Mon. Pneu. Viv. I. 101 ; Cox, Mon. Aust. L. Shells, p. 98, \&c., \&c.

A nat.-Ann. Mus. Gen. xix. pl. 9, figs. 7, 8.

Ty pe in Jardin des Plantes Museum.

H a b.-Yule (D'Albertis), South Cape (Smithurst), Fergusson (Hedley), Woodlark, Trobriand, and Sudest Islands (Kowald and Belford).

99. L. Gianelli, Tapparone-Canefri, 1887.

I 11 u s s.-.Ann. Mus. Gen. xxiv. pl. 2, figs. 10, 11.

D e s c r.

Type in Genoa Museum.

var. alpha, T.-C.

H a b.-Fly River (D'Albertis, Froggatt). 
100. L. Parvum, n.sp.

(Plate XIr. bis, fig. 43.)

Shell small, narrowly perforate, globosely turbinate, thin, translucent; colour light corneous, apex pink; whorls 5, rounded; sculpture, upon the bodly whorl, 15 minute raised spiral lines, 10 above the periphery and 5 below, which latter are confined to the outer half of the base, penultimate whorls encircled by 10 such lines, everywhere microscopically obliquely striated; apex acute; suture impressed; aperture subcircular, peristome almost continuous, slightly expanded and reflected, operculum not observed. Length 6 , breadth $5 \mathrm{~mm}$.

Ty pe in Queensland Museum.

H a b.-Milne Bay (Hedley); one dead specimen.

I overlooked this species until my return to Australia, when I discovered a solitary shell in a bottle filled and closed in Milne Bay. I was in the habit of daily purchasing by the handful shells, beetles, and other small fry from the natives, and I conelude that I received this shell unnoticed among other things.

Recorded from the province in error.

L. venustulum, Tapp.-Can.

Vide Ann. Mus. Gen. xix. 263, arid xxiv. 185.

101. Helicina coxeni, Brazier, 1876.

I 11 u s$^{\text {n. }}$-Ann. Mus. Gen. xix. pl. 9, figs. 12, 13 ; p. 275, fig. g. De s c rn.-P.L.S.N.S.W. (1), I. 111 ; Ann. Mus. Gen. xix. p. 274 .

Ty pe in Macleay Museum.

H a b.-Yule Island (Brazier, D'Albertis) ; Rigo, Port Moresby and Maiva (Hedley). 
102. H. Dentoni, Pilsbry, 1890.

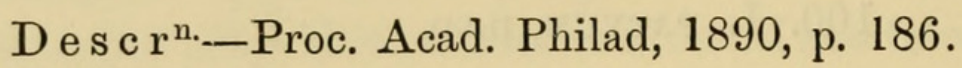

Ty pe in Phil. Acad. Museum.

H a b.-British New Guinea (Denton).

103. H. solitaria, E. A. Smith, 1887.

Ill u s s. Ann. Mag. Nat. Hist. (5), xix. pl. 15, fig. 10.

D e s c r ${ }^{\text {n. }}$-L.c. (5), xix. 425.

$\mathrm{Ty}$ pe in British Museum.

H a b.-Foot of Astrolabe Range (Goldie)?

104. H. Fischeriana, Montrouzier, 1863.

Sy n.-novo-guineensis, Smith, 1887 ; congener, Smith, 1889.

Ill u s ${ }^{\text {n. }}$-Journ. de Conch. XI. pl. 5, fig. 3 ; Ann. Mag. Nat. Hist. (5), xıx. pl. 15, figs. 11, 11a ; l.c. (6), Iv. pl. 13, fig. 17.

D es c rn. -Journ. de Conch. xi. 76, 171 ; Mon. Pneu. Viv. III. 241 ; Ann. Mag. Nat. Hist. (5), xix. 425 ; l.c. (6), Iv. 203.

$\mathrm{T}$ y p e in Bordeaux Museum.

H a b.-Woodlark Island (Montrouzier, Kowald and Belford); St. Aignan (Thomson); Rossel (Kowald and Belford); foot of Owen Stanley Range (Smith).

A large series collected by Messrs. Kowald and Belford at the original locality, and an examination of duplicates of Smith's types in the possession of Mr. Brazier, form the material upon which the above synonomy is based. The locality of Owen Stanley seems to me more than doubtful ; the species is probably confined to the eastern archipelagos. The radiate painting is rarely absent, and with the coarser lyræ serves to define this variable form from its equally variable kin inhabiting the same islands.

105. H. stanleyi, Forbes, 1852.

Ill u s" n.-Voy. "Rattlesnake," Append. pl. 3, figs. 4a, b.

D e s c rn. -L.c. 381 ; Mon. Pneu. Viv. I. 401. 
Ty pe in British Museum.

H a b._Duchatean Islets, Louisiade Archipelago (Forbes).

106. H. insularum, n.sp.

(Plate xır. bis, fig. 44.)

Shell depressedly trochiform, sharply keeled; colour light yellow, usually unicolorous, occasionally with a spiral chestnut band above the periphery, occupying the central third of the space between the keel and the suture, more rarely the band broadens till the keel and a sutural thread alone remain yellow; whorls $4 \frac{1}{2}$, flattened; suture linear; apex acute; sculpture, 9 spiral lyræ above the periphery and 20 below it crossed by close incremental striæ; basal callus well defined, malleated, centre of base smooth; aperture subvertical, lunate, within the basal margin containing a thread-like rib which retreats to the columella, peristome everywhere expanded. Diam. maj. 14, min. 11 , alt. $10 \mathrm{~mm}$.

Ty p e in Queensland Museum.

H a b.-Sudest Island, Louisiades (Kowald and Belford); abundant.

var. sinus, var.nov.

(Plate xII. bis, fig. 45.)

Much smaller than type, six lyræ above, sixteen below the periphery. Diam. maj. 8 , min. 7 , alt. $5 \mathrm{~mm}$.

$\mathrm{H}$ a b.-Village of Mita, Milne Bay, and village of Polatona, Bently Bay (Hedley); abundint, found crawling upon shrubs and trees.

var. muruensis, var.nov.

Diam. maj. 10, min. 8, alt. $6 \mathrm{~mm}$.

Hab.-Murua or Woodlark Island (Kowald and Belford); abundant.

var. trobriandensis, var.nov.

Diam. maj. 11, min. 9, alt. $8 \mathrm{~mm}$.

$\mathrm{H}$ a b.-Trobriand Islands (Kowald and Belford); eight specimens. 
114 the LAND MOLLUSCan FaUna OF BRItish NeW GUiNea,

var. rosselensis, var.nov.

Whorls more convex, colour rose with apex and callus yellow. Diam. maj. 9, min. 8, alt. $7 \mathrm{~mm}$.

$\mathrm{H}$ a b.-Rossel Island (Kowald and Belford) ; abundant.

This species is evidently a dominant form, and may be expected under one of its aspects from any island in the Louisiades and neighbouring archipelagos.

Var. sinus is almost entitled to specific rank ; it makes a distinct advance towards $H$. stanleyi, and in another direction var. rosselensis approaches $H$. woodlarkensis.

107. H. woodlarkensis, E. A. Smith, 1891.

(Plate xir. bis, fig. 46.)

De s c r ${ }^{\mathrm{n}}$-Ann. Mag. Nat. Hist (6), vir. 138.

Ty pe in British Museum.

H a b.-Woodlark Island (Dr. Rabe fide Brazier, Kowald and Belford).

On the visit of the "Merrie England" in 1890, Messrs. Kowald and Belford collected 35 specimens, which are coloured white, yellow, purple-brown or rose, never banded, apical whorls invariably a bright lemon yellow.

My figure is drawn from a specimen of the parcel sent to Smith, kindly lent by Mr. Brazier.

108. H. Louisiadensis, Forbes, 1852.

I 11 u s" -Voy. "Rattlesnake," Append. pl. 3, figs. 5a, b ; Sow. Thes. Conch. Iv. pl. 275, figs. 349, 350 ; Conch. Icon. xix. pl. 29, figs. $257 \mathrm{a}, \mathrm{b}$.

D e s c r"-Voy. "Rattlesnake," II. p. 382 ; Mon. Pneu. Viv. I. p. 385 .

Ty p e in British Museum.

H a b.-Round Island, Coral Haven, Louisiades (Forbes); Milne Bay and Basilaki Island (Hedley).

The mainland examples are rather larger and more depressed than the shells described by Forbes. 
109. H. maino, Brazier, 1876.

(Plate xir. bis, fig. 47.)

D e s c r ${ }^{\text {n. }}$ P.L.S.N.S.W. (1), I. 112 ; Ann. Mus. Gen. xIx. 276, xxiv. p. 188.

Ty pe in Macleay Museum.

H a b.-Village of Mowatta, Katow River (Brazier).

Drawn from the type by the kind permission of Mr. Masters, Curator, Macleay Museum.

"Maino" signifies "peace" in the local dialect.

110. H. multicoronata, n.sp.

(Plate XII. bis, fig. 48.)

Shell minute, globosely conical ; colour dull yellow ; whorls $4 \frac{1}{2}$, rounded, slightly turreted; sculpture, upon the last whorl a fine thread-like keel at the periphery, the space between that and the suture divided by three similar keels, the earlier whorls exhibit only the three upper keels, each keel bears minute, erect, epidermal bristles, which give the shell a somewhat coronated appearance under the lens; base rounded, faintly concentrically and longitudinally striated; callus smooth, semi-transparent; aperture vertical, semi-lunate, red within, lip slightly expanded. Diam. maj. 4 , min. $3 \frac{1}{2}$, alt. $4 \mathrm{~mm}$.

Ty p e in Queensland Museum.

H a b. -. Village of Mita, Milne Bay (Hedley); one specimen.

Doubtful.-H. leucostoma, Tapparone-Canefri (Ann. Mus. Gen. xIx. p. 277 , fig. $\mathrm{h}$ ), may belong to this province, but the locality is not defined by the author.

\section{(Anatomical Supplement to follow.)}

EXPLANATION OF PLATES.

Plate ix.

Figs. 1, 2. -Oxytes hercules, Hedley.

Figs. 3, 4. -O. Ayensis, Hedley.

Fig. 5. -Conulus starkei, Brazier. Magnified.

Fig. 6. -C. maino, Brazier. Magnified.

Fig. 7. -Microcystina sappho, Brazier. Magnified.

Fig. 8. $-M$. calcarata, Hedley. Magnified. 


\section{EXPLANATION OF PLATES (continued).}

Plate $\mathrm{x}$.

Fig. 9. -M. calcarata, Hedley. Magnified.

Fig. 10. -Thalassia annula, Brazier.

Fig. 11. -Ochthephila albertisi, Brazier.

Fig. 12. -Charopa texta, Hedley. Magnified.

Fig. 13. - Helicarion visi, Hedley.

Fig. 14. - -H. musgravei, Hedley.

Figs. 15, $16 . \quad-$ Rhytida globosa, Hedley.

Figs. 17, 18, 19.-Cristigibba macgregori, Hedley.

Fig. 20. -Geotrochus oxystoma, Smith.

Plate Xi.

Fig. 21. -Geotrochus oxystoma, Smith.

Figs. 22, $23 . \quad-$ G. bevani, Brazier.

Figs. 24, 25. -G. elisus, Hedley.

Fig. 26. -G. tapparonei, Smith.

Fig. 27. --G. zeno, Brazier.

Fig. 28. -G. trobriandensis, Hedley.

Fig. 29. -G. brumeriensis, Forbes.

\section{Plate xir.}

Fig. 30. -Cochlostyla papuensis, Hedley.

Fig. 31. - Partula occidentalis, Hedley.

Fig. 32. -Succinea simplex, Pfeiffer.

Fig. 33. -Omphalotropis brazieri, Hedley. Magnified.

Fig. 34. -O. protracta, Hedley. Magnified.

Fig. 35. -Bellardiella minor, Hedley. Magnified.

Fig. 36. - - Pupinella tapparonei, Brazier. Magnified.

Fig. 37. -Pupina ovalis, Hedley. Magnified.

Fig. 38. -P. gibba, Hedley. Magnified.

Fig. 39. -Diplommatina symmetrica, Hedley. Magnified.

Plate XII. bis.

Fig. 40. -Cyclotus horridus, Hedley. Magnified.

Fig. 41. -C. kovaldi, Hedley. Magnified.

Fig. 42. - C. belfordi, Hedley. Magnified.

Fig. 43. -Leptopoma parvum, Hedley. Magnified.

Fig. 44. - -Helicina insularum, Hedley.

Fig. 45. - , , , var. sinus. Magnified.

Fig. 46. $\quad-H$. woodlarkensis, Smith. Magnified.

Fig. 47. - $-H$. maino, Brazier. Magnified.

Fig. 48. - -H. multicoronata, Hedley. Magnified. 


\section{$2 \mathrm{BHL}$ Biodiversity Heritage Library}

Hedley, Charles. 1891. "The land molluscan fauna of British New Guinea." Proceedings of the Linnean Society of New South Wales 6, 67-116. https://doi.org/10.5962/bhl.part.29877.

View This Item Online: https://www.biodiversitylibrary.org/item/30437

DOI: https://doi.org/10.5962/bhl.part.29877

Permalink: https://www.biodiversitylibrary.org/partpdf/29877

\section{Holding Institution}

MBLWHOI Library

\section{Sponsored by}

MBLWHOI Library

\section{Copyright \& Reuse}

Copyright Status: NOT_IN_COPYRIGHT

This document was created from content at the Biodiversity Heritage Library, the world's largest open access digital library for biodiversity literature and archives. Visit BHL at https://www.biodiversitylibrary.org. 